\title{
Literature and Truth in Enrique Vila-Matas
}

\author{
Vicente Lozano Díaz \\ Francisco de Vitoria University, Spain \\ Carmen Romero Sánchez-Palencia \\ Francisco de Vitoria University, Spain
}

\begin{abstract}
A postmodern approach helps the Spanish novelist Enrique Vila-Matas overcome the dichotomy between literature and reality and between desire and facts as the solution is to combine both elements. However, this does not mean he accepts all postmodernist characteristics, as accepting hermeneutic truth allows him to propose an aesthetic and even moral ideal that affirms the existence of a truth and certain values that go beyond absolute postmodern relativism.
\end{abstract}

Index Terms - literature, reality, fiction, truth, morals

\section{INTRODUCTION}

By 2010 the Spanish author Enrique Vila-Matas was enjoying great success in his career as a writer. He had achieved popularity with readers with his works translated from Spanish into over thirty languages, he was well regarded by specialist critics, and he had been recognised by official institutions. In fact, in the space of just a few years, he published, among other texts, the ones that are almost unanimously regarded as his best works, the books that comprise what his then publisher, Jorge Herralde, called La Catedral Metaliteraria (The Metaliterary Cathedral) Vila-Matas (2008b). This trilogy comprises the novels Bartleby y compañía (Bartelby and Company), published in 2000 and winner of prizes such as the Ciudad de Barcelona in Spain, the prize for the best foreign book published in France and the Fernando Aguirre prize from French booksellers, El mal de Montano (Montano's Affliction), published in 2002 and winner of prizes such as the Herralde prize for novels and the Premio Nacional de la Crítica in Spain, the Círculo de Críticos de Chile prize, the Médicis prize for the best foreign novel published in France and the Ennio Flaiano international literature prize in Italy, and finally Doctor Pasavento, published in 2005 and winner of the Real Academia Española prize and the Fundación Lara prize for the best novel of the year in Spain and the Mondello international literary prize in Italy. In 2006 he was also made a Knight of France's Legion of Honour in recognition of his work as a whole.

In the midst of this official and public recognition and with his next novel, Dublinesca (Dublinesque) - another immediate success - about to appear, Vila-Matas published a short book called Perder teorías (Losing Theories) which went largely unnoticed. In this text, mid-way between narrative and essay, he presented what he called "the elements - inescapable, essential - that should feature in any future novel that aims to be relevant to the new century" Vila-Matas (2010). He would adhere closely to these five criteria in his forthcoming novel, but they were also already apparent in his earlier works and, indeed, they comprise a general theory of the novel or a true literary theory that can function as an ideal tool for analysing the constant aspects present in all of his work, as well as his basic intentions. These five essential features are:

1. "Intertextuality" (in inverted commas).

2. Connections to fine poetry.

3. Writing as a clock moving forwards.

4. The dominance of style over plot.

5. An awareness of a ruinous moral landscape. Each of these aspects will now be considered in depth.

\section{II. "INTERTEXTUALITY"}

In various explanatory texts and interviews, Vila-Matas places his work in a tradition starting with the great Modernist authors such as Charles Baudelaire, Herman Melville, James Joyce, Marcel Proust, Franz Kafka, Fernando Pessoa and Robert Walser and continuing with other writers like Jorge Luis Borges, Italo Calvino and Vladimir Nabokov, authors who use their oeuvre to enquire into the unity that underlies all of the multitude of forms and manifestations in which modern human existence occurs, who seek out the essence or meaning of the reality that surrounds them in order to find their own place in it. Situated in a reality that simultaneously includes and disconcerts them, these authors stop seeing art in general and literature in particular as a mere entertainment. Instead it becomes a privileged instrument that makes it possible to understand the spirit of the age and find its deepest meaning. The aim, then, is to go somewhere neither philosophy nor science can reach, weighed down as they are by their rationalism and methodological rigour and their aspiration to exhaustive explanation. 
This current in postmodernism eventually culminates in a series of authors who turn the question about the essence and meaning of reality into one about the status of fiction and it relationship with reality. These are authors, such as Claudio Magris, W. G. Sebald and Sergio Pitol who propose a new path for the novel, one that Vila-Matas explicitly follows:

In Bartleby y compañía, by mixing essays with narrative, I merely joined a contemporary line in a way that I felt was almost innate to me and in any case derived from my Historia abreviada de la literatura portátil (A Brief History of Portable Literature) - the line of the Magris of Danube, or the Pitol of El arte de la fuga (The Art of Escaping), or the Sebald of The Emigrants - one that proposes a different path for the novel, a path that combines essay and narrative. (...) It is a way of defining this genre, which is gaining ground in the contemporary novel. It is a hybrid genre that stands out as a mixture of autobiography, reportage and invention. It is a genre that suggests broadening the terms of the novel. In English it is called <<faction>>, another example of their capacity for synthesis and their pragmatism and ingenuity when classifying things Vila-Matas (2013).

The word "faction", combining "fact" and "fiction", perfectly summarizes this new current that fully and deliberately forms part of the postmodern plurality announced by Nietzsche and described by authors such as Foucault and Baudrillard. There is no longer a single structure underpinning reality that we can know, nor is there even a single representable reality or totality but instead all sorts of realities or forms of existence that touch, collide, superimpose and separate, generating all sorts of mixtures and combinations, a plurality comprising multiple heterogeneous elements that occur successively. The real is not just what happens or is produced, but also what each subject feels or experiences, even what they imagine. The essence is no longer in the actions of the subjects but instead in their behaviour, behaviour that includes their actions along with what they feel, experience, desire, fear or imagine while acting.

But if fiction can be part of reality, then a novel is real, it is part of reality, it exists, so what stops reality from being part of fiction? More consciously and radically than in Modernist authors, the response to the dichotomy between the real and the literary, between what happens and what is imagined or desired or feared, is no longer for one aspect to win out over another but instead for the two to fuse. It is a matter of finding the intermediate space between the two where people become and dwell; writing no longer tries to explain the world but instead aspires to expand the boundaries of the human, as all that exists outside the text is another text. The imagination no longer distances us from reality; it is the key that gives us access to its inner walls. Consequently, works are produced in which the factual and the imaginary combine, documents combine with fiction, the author's own texts and texts by others, and in which everything is true because everything is invented. In the language of the Classics: Fortis imaginatio generat casum, a strong imagination begetteth chance.

It is with this conception as his starting point that Vila-Matas regards intertextuality, or the explicit links one text has with another text, as an unavoidable characteristic of the twenty-first century. "Intertextuality", he states, is not something negative but rather something unavoidable: "We should not fool ourselves: we always write after others" Vila-Matas (2010). Although this is something that should be used appropriately, not comprising mere plagiarism or repetition of someone else's content. Authors draw on the materials life provides, but they also grow "mysteriously" based on other books, using these materials that have become part of their own experience if they "welcome them warmly", if they "absorb" and "transform" them in their own presentation. This is a process of welcoming, absorbing and transformation, a legitimate appropriation that Vila-Matas tries to specify when he states that he supports "intertextuality" in inverted commas. In his work it reaches a point where real quotations and references are mixed with other completely invented ones in a process he describes as a complex but joyous game Vila-Matas (2010).

\section{CONNECTIONS With Fine POETRY}

Of the five essential features of the literary theory Vila-Matas proposes in Perder teorías, the second (connections with fine poetry) is among the less well explained ones, with just a few brief reflections and statements about how important it is for the novel never to lose its subtle connections with fine poetry, about how desirable it is to combine surrealism, metaphysics and primitive myths in an original way, and finally, personal memories of the impact some works had on him, especially Julien Gracq's work which is omnipresent throughout the book, and By Grand Central Station I Sat Down and Wept by Elizabeth Smart.

However, we agree with Júlia González de Canales when she notes in her study of Vila-Matas that the observations in question show that the second feature "does not so much refer to the inclusion of poetical stanzas in the body of the narrative but rather to the possibility that the text itself maintains a lyrical attitude" Gónzalez de Canales (2016). It is therefore a matter of the text being stylized and never losing its connections to fine poetry and its capacity for dialogue with the poetical tradition, thus becoming a narrative-poetical text that enables different meanings to be created. This aspect is fundamental for distinguishing between a novel that is good and one that is not.

\section{WRITING AS A ClOCK MOVING FORWARDS}

Vila-Matas also does not provide any specific explanation in this text of the third feature he describes, writing as a clock moving forwards. However, in this case we do have the help of other texts by him in which he tackles this 
question, in particular the article "Mastroianni-sur-mer", included in the collection El viento ligero en Palma (Light Wind in Palma), published in Mexico in 2004 and republished in Spain in 2008.

In this article, quoting Claudio Magris, he notes that "writing involves transforming life into the past, in other words, aging", making it clear in the rest of the article that this aging process does not mean giving up or stopping, taking refuge in mere nostalgia for the past, but, on the contrary, ushering in nostalgia for the future Vila-Matas, (2008). The writer thus becomes someone who perseveres, who understands that we inhabit the passage of time as possibility or change, and who therefore constantly maintains an open and creative attitude to the world and other people, someone who becomes, who evolves in his own process of development. Remembering moments or events from his childhood, some real and some invented, is common in Vila-Matas's own writing, and it consequently does not mean pausing but instead forms part of this process of becoming in the passage of time, as one always remembers from the present looking towards the future.

It is through writing that the writer becomes aware of time, settling into a temporal ecstasy or eternal present in which what has already been or could have been, what is being and still has not been or may yet be, coincide. A temporal conjunction or intersection of possibilities from which the writer relates to reality, thus becoming a subject. This aspect is intimately related to the fourth feature of poetics he presents, the dominance of style over plot.

\section{The Dominance of Style over Plot}

After putting forward "intertextuality", connections with fine poetry and writing as a clock moving forwards, VilaMatas explains the most recognisable feature of his theory of literature, the dominance of style over plot, a feature that is in a way prepared or framed by the previous ones. He goes on to describe how the work of Gracq and comments by authors such as John Banville helped him to free himself from a commonly held view that had worn him down since his youth, the idea that plot should be privileged over style when telling a story Vila-Matas (2010).

It is evident that if we position ourselves in the realist tradition, in which, in Stendahl's famous expression, a novel is a mirror carried along a high road, the essence of a narrative is what it depicts and how it depicts it, what it describes or explains. But if literature is no longer seen as a narration about the world and becomes its effect on the world, if the text stops being seen as a description of reality and the subjects that inhabit it and instead becomes the creation of a reality where a continuously open process occurs in which the author becomes himself, then the style becomes the essence, allowing the author to understand something of himself and the potential reader to receive content that can be used to create and understand their own circumstances.

In line with the postmodern philosophical tradition that runs from Friedrich Nietzsche to Jacques Derrida and Michel Foucault, and in the literary strand described above of Claudio Magris and W. G. Sebald, Vila-Matas claims that the world is no longer experienced as an absolute totality that is ordered and predictable but instead has become something fragmentary and driven by chance, a plural structure comprising all manner of heterogenous elements that break with any expectations and that cannot be reflected in great plots, Roas (2007). There is no longer a totality of meaning to impart the objective facts, rationalism and conditions of any constituent discourse and within which the life of a subject develops, a subject that is created in accordance with the processes of subject formation and that expresses or explains its own subjectivity through the acceptable discourse, either in an essay or a novel.

Writers can therefore no longer aspire to explain the world, but instead through their own discursive form they can attempt to reflect a fragment or moment of this world in which they can construct and understand themselves. As stated by the protagonist of El mal de Montano, the author's alter ego, at a point where literature is being discussed:

I make the word. And I make theory, and I tell you, I share with monsieur the idea that the world can no longer be recreated like in the old novels, that is, from the writer's unique perspective. Monsieur and I believe that the world has disintegrated, and one can only offer a credible image if one dares to show it in its dissolution, Vila-Matas (2002).

This process of composition is the key to "the disappearance of the subject", the true leitmotif of Vila-Matas's metaliterary trilogy. One way or another, the protagonists of these three novels, each one a different representation of the author, attempt to disappear, but this disappearance is not so much a will to cease existing materially or physically but rather a desire to become their own self, to invent this self outside the accepted rules and procedures, a desire to turn into someone who happens or occurs, tracing, and achieving or not achieving their own possibilities in the passage of time, going beyond what social mores consider legitimate, normal or productive, a desire to become a flâneur wandering around, Oñoro (2015).

Consequently, all of Vila-Matas's works are an expression of this poetic principle in which style takes precedence over the plot. Whether they are novels or essays, they form a mosaic of texts, readings, citations and memories, real or not, that comment on each other and metamorphosize, breaking with the idea of a narrative continuum or a higher logic to which they must answer. They are stories that create themselves in the course of their own writing, a narrative of events that sketch a chance counter to any idea of need and independently of the narrative causality of realist literature, tapestries that weave themselves capriciously in multiple directions, and in which philosophical reflection mixes with a fragment from a newspaper, a scene in a film, an anecdote or a biographical event, building a shared territory where the invented and the true coexist, Pozuelo Yvancos (2010), and on which basis the author builds his subjectivity or represented self at the same time as making it available to his own consciousness and that of others. 


\section{AN AwARENESS OF A RUINOUS MORAL LANDSCAPE}

The fifth feature of Vila-Matas's proposed poetics, an awareness of a ruinous moral landscape, combines and uses the four previous features, giving the set a certain coherence. Consequently, it states that just as a work of literature should be like a clock moving forwards, in other words it should maintain a creative attitude towards reality and look to the future; it must also be like a mirror that moves forwards. This ability to move forwards does not mean that it becomes a prophetic literature, something that is not at all interesting, but that it is a work of perception that can prefigure a moral landscape, making it possible to understand better the present. He mentions Kafka's work, in which waiting is the essential condition of the human being, and, again, The Opposing Shore by Julien Gracq as:

Gracq's book is in this current of authors with mirrors that move forwards. It appears to be aware of the core of our current problem: the situation of absolute impossibility, the individual's powerlessness in the face of the devastating machinery of power, of the political system, Vila-Matas (2010).

According to Vila-Matas, from the 20th century onwards, politicians and writers, history and poetry, started speaking two different languages. Furthermore, after the end of the Second World War, there was nothing that could be narrated left in the continent as everything had now happened, and so, with nothing left to happen, we came to live in a painful nothingness, Vila-Matas (2010). After the storm, we submerged ourselves in pure endless activity, a "great void caused by that immense pride of thinking that, with the gods dead, we are the only immortals in existence". An absolute void, the absolute decadence of the western world and of modern life, the nullification of people under the socio-political machinery and mere instrumental or survival activities, in the face of which a true literary work must offer the possibility of utopia, Vila-Matas (2010).

This statement about how the genuinely literary has an undoubted moral mission could at first be somewhat disconcerting, and yet it is something that is present throughout Vila-Matas's oeuvre. Without looking further, in El mal de Montano, mentioned above, the sickness of a literature reduced, on the one hand, to publishing just bestsellers that contribute nothing, and, on the other hand, to the leaden deconstruction or merely theoretical analysis of literary texts is denounced:

If someone should be off their map, it is me; I am an old-fashioned critic, one who opposes the ferocious and Kabbalistic jargon that has spread through universities in the United States, where professors and critics speak of literature with such indifference towards the aesthetic, moral or political element of literature strictly speaking that it could be said that it has disappeared under the rubble of theory, Vila-Matas (2002).

Vila-Matas maintains that literature is, in effect, under assault from an almost endless number of dilettantes, who write without having any particular capability, and is being subjected to a merely commercial perspective that turns everything into a product, plunging readers into a state of great confusion, all of this without it being defended in any way by professors and critics who spend their time deconstructing literary texts with no purpose beyond simple intellectual games. Therefore, Vila-Matas goes so far as to affirm that:

As for literature, it has almost disappeared. I also think that ninety-nine per cent of people do not know what it is. This is what some of my least-understood books in Spain cover, Vila-Matas (2013).

Consequently, he defends a literature that points to something more, that is critical of the present and can harbour a utopia or hope, that simultaneously has an aesthetic, moral and political aim. This aspiration seems hard to reconcile with Vila-Matas's apparent acceptance of a postmodernism characterized by its most radical relativism and by accepting the absence of truth as the ultimate truth. And yet it is possible to say that these two aspects are consistent with each other, so long as it is understood that the truth Vila-Matas defends goes far beyond simple relativistic postmodernist truth and is actually much closer to the concept of truth in the hermeneutics of authors such as HansGeorg Gadamer.

\section{HERMENEUTIC TRUTH}

As is well-known, the traditional concept of truth is what is known as truth as correspondence, a concept upheld by realism and the only one apparently acceptable to common sense.

According to realism, facts or events that exist in the real world have a single, specific manner: what has happened is what has happened, what someone says or thinks is something concrete and specific, this table is like this, and so on. On this basis, we can establish that truth is how human understanding corresponds with the thing or fact that exists or occurs: the object. Truth is the correspondence between what is in one's comprehension and what the object is, and so truth and knowledge are closely linked. Knowledge is the relationship between a subject and an object, a process by which the subject leaves its sphere and captures the features of the object before returning to itself and being aware of what has been captured. The subject forms the image of the object in this way — not, however, naïvely - since it necessary to consider that what is understood is included in the subject's experiential relationship and through its own cognitive structures. Knowledge is not the object as it is in itself, but rather the representation or image the subject makes of the object, and this representation can be accurate or inaccurate. If the features of the object are somehow reproduced in the image, the knowledge is true; if there is a discrepancy, it is not true. It is erroneous.

Truth or non-truth is thus a first level in representation and a second level in the combination of representations or judgement, and it is defined as the combination or concordance of the content of the representation, or of the content of 
the combination of representations, with the object, while the object cannot be true or not-true; it is what it is in itself. If I say, "This table is white", the truth or falsehood is not in the table, the object itself, but instead in the statement about the object, in the judgement or combination of the representation "table" and the representation "white" that refers to the object. This judgement will be true or false according to whether the representation I make in my mind matches the object (whether or not it is a table), and according to whether or not the link I make in my mind between the representations agrees with the link that is made in the object (whether or not it is a white table).

This traditional concept is what relativism questions, especially since Nietzsche in the late nineteenth century. Relativism claims that there is never a direct access to the fact or the thing — the object — that my personal structure is always between the object and the ego. This structure includes physiological elements as well as my own experiences, desires, fears, and so on. In other words, if five people are looking at a table, the table does not have a single form and the people who look at it or judge it do not approach this form and the truth with more or less success, but instead the table has five forms, one for each person, all of which have the same truth. They are all real.

It is not true that there is an object that exists or is produced in a single form, since the table is only a table for human beings. It is human beings who give the sense or meaning of table to something that is there, and without human beings this could be any other thing, but not a table. Consequently, according to Nietzsche, there are no facts but instead only interpretations of the facts, different interpretations by each person who contemplates the fact from their own circumstance and experience, seeing it or introducing their own desires and meanings into it, Nietzsche (2004). For some the table might be large, for others small, for some, beautiful, for others ugly, and so on. No one interpretation is better than any other, although one will generally impose itself through convenience, conviction or the will of the strongest party. Therefore, there is no truth, strictly speaking, and the world is not a fact but rather an invention, a set of observations in constant flux, Nietzsche (2006).

Finally, the concept of hermeneutic truth appears between truth as correspondence and relativistic truth. This follows the phenomenological tradition and is expressly formulated by Hans-Georg Gadamer in his work Truth and Method from 1960. According to this new approach, the concept of truth as correspondence based on the match between the representation or image in the mind of the subject and the exterior object in question cannot be denied. This correspondence, furthermore, can be checked or verified through sensory experience. This is the objective truth of the physical-mathematical or experimental sciences; in more specifically human experiences, we find another type of truth. When analysing the writings of a philosopher, we study a fact from the past. We apply general legal rules to a specific case or we reflect on divinity. When we contemplate a painting, we face the representation of a spectacle. When we read a poem or listen to music, we access a truth that cannot be verified in the same way that statements about the material world are verified.

In the experience of art, the experience of philosophy or any experience of the historical tradition that goes beyond simple investigation or listing of facts, we do not restrict ourselves to empirical knowledge of something that is merely external to us or in front of us, like the objects of science in relation to the subject, but instead we occupy ourselves with something that involves and affects us, something we are trying to understand. This is not a piece of content relating to knowledge that can be disconnected from us or that is mentioned objectively; it is a possibility of ours, a knowledge that is simultaneously self-knowledge. When understanding something like a historical fact or a poem, we experience it in a way that goes beyond the merely objective and we access a comprehensive or extra-scientific truth that we connect using all of our experience of the world. Consequently, we are concerned with how we are and how we feel, how we live. We understand ourselves and participate in a hermeneutic or understanding universe in which we are open, Gadamer (1977).

There is, therefore, no rejection of knowledge or of the objective truth that the physical-mathematical or experimental sciences provide, but instead the affirmation that these objective types of knowledge and truths must be completed by another different type of knowledge or truth, the knowledge or truth that appear in various participation-based experiences of the human being. These experiences even predate merely objective experiences, and in them the human being seeks a meaning or foundation, a place in this totality of which the individual is part, in which we participate, and which we call reality or world. This is not a case of subjects who encounter a work of art or a text that transmits a conceptual meaning to them, but of subjects who face something that occurs and consequently come to know themselves. They access the hermeneutic truth and become aware of themselves as specific parts of the totality that is the world, while at the same time, what has occurred takes shape and acquires a full identity; it is there as what it is and only as what it is, in itself and not as a mere construct.

However, this means that for the aesthetic experience that makes it possible to access hermeneutic truth to occur, it is not enough for a person to contemplate a painting or attend a theatre production as a spectator. The aesthetic experience requires subjects to react with passion and go beyond the objective appearance of the work, for there to be a play of representation in which subjects let themselves go completely, ceasing to be dominant consciousnesses while the work simultaneously acquires meaning and identity insofar as it happens or is created, in that someone contemplates or watches it, Gadamer (1977).

According to Gadamer, aesthetic experience is not fully subjective or fully objective. Instead, it is a participatory process in which the subject in some way loses its identity in order to recover it more fully. A theatrical performance needs the ensemble made up of the actors who by performing the play enable it to occur or make itself present, and 
spectators before whom the play occurs. On the one hand, the play occurs or is created, the reality becomes manifest, and on the other hand, the subject who experiences this reality is transformed, Zúñiga (1995). This requires a series of clarifications:

1. Firstly, and unlike what happens in the traditional theory of knowledge used in the natural sciences, in aesthetic comprehension it is not possible to distinguish between truth and meaning. According to the traditional theory of knowledge, a fact or judgement has meaning if it is rational, if it refers to something, if it has a purpose or an aim. Only then can there be truth or non-truth, something that must be verified or tested by experience. But if there is meaning in aesthetic comprehension, there is already truth. The truth or meaning is the thing that happens and that subjects incorporate into their experience of the world and of themselves. Furthermore, there cannot even be false or erroneous aesthetic comprehension, but instead something occurs or does not occur, hermeneutic truth happens or does not happen.

2. Secondly, if a human being's comprehension of a work of art or a text from the past is mediated by this person's particular characteristics and by the era inhabited, then it is shaped by the individual's own historical perspective. This appears to lead to relativism, to the claim that works of art and historical texts do not exist in themselves, that they do not have a unique meaning, that there is no absolute truth, just different possible interpretations. But according to Gadamer, works of art or historical texts do exist in themselves. What happens is that they do not reveal themselves in a single situation or moment as a completed whole, but they gradually reveal different aspects of themselves, they create themselves, based on the different aesthetic experiences or historical understandings that derive from different subjects and come together to form the work of art or historical text, giving them their meaning or truth. Hamlet did not end when Shakespeare decided he had completed it; instead, every time someone attends a performance of Hamlet or reads it and is moved by it, this experience also forms part of Hamlet. Despite Gadamer's hermeneutics frequently being described as relativistic, he believes that seeing truth as something purely historical does not lead to relativism, as in its process of development the truth becomes objective and rises above the subjective contingency of any starting point.

\section{The Hermeneutic Truth OF VILA Matas}

As we have seen, postmodernism enables Vila-Matas to overcome the dichotomy between literature and reality, between what we live and what we feel or imagine or desire, as the answer lies in the fusion of the two, Zoe (2007), in turning the house of fiction into the most secure reality, Vila-Matas (1996: 193). But this does not involve accepting all of postmodernism's features, since accepting hermeneutic truth makes it possible to propose an aesthetic and even moral ideal, and affirm the existence of a truth and some values that go beyond absolute postmodern relativism that cannot postulate something beyond the perspective of each individual. This truth, however, can no longer just be truth as correspondence as this is too closely linked to traditional realism and common sense. It is instead in the hermeneutic truth analysed here, the truth understood as each individual's participation based on personal experience in the process of establishing the sense or meaning of the reality in which we all find ourselves. As Vila-Matas himself notes:

(...) our minds are more connected than it seems: in reality we comprise a Whole. What I am telling you here is not literature, but an impression I had in that moment of youth that for me counts as another experience that I think it is much better not to forget. (...)

Everything I have written recently is true or tries desperately to approach the truth. I do not like lying at all. This does not erase the fact that - youthful transgressions - I sometimes went too far with certain literary games. But nowadays these games, if I still play them at all, are more refined. Nowadays I only write because I think it can bring me closer to the truth, however much this truth might turn out just to be mine. Just mine? In this way of thinking - I am referring to the mental communication between all humans - it will eventually be the (relative) truth of all of them. Vila-Matas (2013)

It would be hard to find a passage where Vila-Matas is more explicit about the intentions of his work; he writes to approach the truth, to propose a truth in which other human beings can come to participate. This is possible because those human beings participate in "a Whole", they have an intrinsic communication that makes them simultaneously form part of a process in which each one of them develops according to their own specific character.

Without ceasing to be postmodern, Vila-Matas goes a step further, as communication between all human beings who form part of a group is precisely what makes it possible to propose a poetics and a morality, certain considerations or ideals regarding reality that transcend the unavoidable and accepted individualistic postmodernist perspective. The author relates to reality through literary writing. He creates his subjectivity or personal identity, he understands himself, but he also in his own way participates in the truth, in the collective process of creating the framework or general context within which other individuals can also create themselves. However, Vila-Matas suggests that the author should do all of this by being playful and by mixing what he has received with what he is, in an intertextual game, without abandoning beauty or fine poetry, creatively projecting himself onwards like a clock moving forwards, concerning himself more with aspiration than data, with style more than plot, and, finally, maintaining a moral exigency or a demand for authenticity when faced with a reality that tends to annul him in its various processes of consumption and power.

The act of writing then becomes an act of mixing all sorts of situations and representations, biography and the imagined, in which the author creates his own literary identity. Writing is what allows the author to enter this intermediate space between the real and the imaginary which we call utopia, where it is possible to understand the 
meaning of existence and reality itself by expanding the boundaries of the human. This space is also one that the author offers to his readers for them to use as they see fit, and therefore it is true, because it is experienced and can to a certain point be shared, but it is a space for which the author pays the price of definitive alienation and the impossibility of coping with the everyday world. Consequently, literature is simultaneously the poison and the medicine, the illness and its cure (Pozuelo Yvancos, 2010: 140) as it enables the reader to understand life, albeit at the cost of being outside it, as recognised by the protagonist of El mal de Montano, one of the representations of the author:

Therefore, I can now calmly say that, between life and books, I would choose books as they help me understand life. Literature has always helped me understand life. But for that very reason it leaves me outside it. I am serious; it is fine this way, Vila-Matas (2002).

\section{REFERENCES}

[1] Gadamer, Hans-Georg. (1977). Verdad y método. Salamanca: Sígueme.

[2] González de Canales, Júlia. (2016). Releyendo a Enrique Vila-Matas. Placer e irritación. Barcelona: Anthropos.

[3] Nietzsche, Friedrich. (2004). Crepúsculo de los ídolos. Madrid: Alianza. First edition, 1973.

[4] Nietzsche, Friedrich. (2006). Fragmentos póstumos (1885-1889). Vol. II. Madrid: Tecnos.

[5] Oñoro, Cristina. (2015). Enrique Vila-Matas. Juegos, ficciones, silencios. Madrid: Visor Libros.

[6] Pozuelo Yvancos, José María. (2010). Figuraciones del yo en la narrativa. Javier Marías y E. Vila-Matas. Valladolid: Universidad de Valladolid.

[7] Roas, David. (2007). "El silencio de la escritura (A propósito de Bartebly y compañía)", in Irene Andrés-Suárez and Ana Casas (Eds.), Enrique Vila-Matas. Neuchâtel-Madrid: University of Neuchâtel - Arco/Libros, pp. 141-152.

[8] Vila-Matas, Enrique (1996). "El río de la invención”, in Enrique Vila-Matas, El traje de los domingos. Madrid: Huerga y Fierro, pp. 191-193.

[9] Vila-Matas, Enrique. (2002). El mal de Montano. Barcelona: Anagrama.

[10] Vila-Matas, Enrique. (2008a). "Mastroianni- sur-mer", in Enrique Vila-Matas, El viento ligero en Parma. Madrid: Sextopiso, pp. 21-47. First edition, 2004.

[11] Vila-Matas, Enrique. (2008b). "Breve autobiografía literaria", in Enrique Vila-Matas, El viento ligero en Parma. Madrid: Sextopiso, pp. 207-215. First edition, 2004.

[12] Vila-Matas, Enrique. (2010). Perder teorías. Barcelona: Seix Barral.

[13] Vila-Matas, Enrique. (2013). Fuera de aquí. Conversaciones con André Gabastou. Barcelona: Galaxia Gutenberg.

[14] Zoe, Irene (2007). "El diálogo supratemporal frente a la impostura literaria. Claves para descifrar la obra de Enrique VilaMatas", in Irene Andrés-Suárez and Ana Casas (Eds.), Enrique Vila-Matas. Neuchâtel-Madrid: University of Neuchâtel Arco/Libros, pp. 49-63.

[15] Zúñiga, José Francisco (1995). El diálogo como juego. La hermenéutica filosófica de Hans-Georg Gadamer. Granada: University of Granada.

Vicente Lozano Díaz is Professor of Humanities and Metaphysics at Universidad Francisco de Vitoria, Madrid (Spain). PhD Degree in Philosophy by Universidad de Barcelona (Spain) with the Tesis on The Aritotelic Notion of First Philosophy, with the grade cum laude, 2004.

Publications (ORCID: 0000-0002-4443-2257):

- Book chapter: Vicente Lozano Díaz, V., "Entre comunismo y liberalismo: la teoría del estado en Hegel" in the book entitled: Experiencias y manifestaciones culturales de vanguardia, 2016, McGraw-Hill, Madrid, Spain.

- Book: Lozano Díaz, V., Existir como posibilidad. La ontología fundamental de Martin Heidegger, 2016, Dykinson, Madrid, Spain.

- Article: “Actualización docente: La postmodernidad y la película de Matrix" (Teaching Update: Postmodernity and the Film Matrix), 2015, Opcion, Vol. 31, pp. 1086-1103, Venezuela.

- Article: Lozano Díaz, V.: "La cuestión de la moral en Ser y tiempo de Martin Heidegger", 2015, Arbor, 191 (774): a255, Madrid, Spain.

He was Coordinator of the Department of Humanities of the UFV and Vice Rector of the University (2009-2014). Research Focused on: Philosophy (Metaphysics, Ethics) and Literature.

Doctor Vicente Lozano Díaz is a member of several research projects about ethic and hermeneutic. He is, also, a member of the editorial thinking collection of UFV, Spain. He has won a lot of awards for his teaching work.

Carmen Romero Sánchez-Palencia is Professor of Humanities at Universidad Francisco de Vitoria, Madrid (Spain). Doctor in Social Sciences and Humanities with the Tesis on Thomas Stearn's Eliot defended in Madrid (Spain), 2012.

Publications (ORCID: 0000-0002-1460-605X):

- Book: Romero Sánchez-Palencia. C., Existencia y Literatura. La teoría como provocación en T. S. Eliot (Existence and Literature: Theory as Provocation in T. S. Eliot), 2015, Dykinson, Madrid, Spain.

- Book chapter: Romero Sánchez-Palencia. C., "Anuncio, esperanza y encuentro: la problemática de lo humano en Azul, Blanco y

Rojo de Krzysztof Kieślowski" in the book entitled: Innovación y vanguardias universitarias, 2016, McGraw-Hill, Madrid, Spain.

- Article: Romero Sánchez-Palencia, C., "The Unity of Plurality: Literary Effects in the 19th and 20th Centuries", pp. 1137-1141, 2016, Theory and Practice in Language Studies, Academy Publication, UK, Vol. 6. No. 6, June. 
She was Deputy Director of a University Women's Hall of Residence and Coordinator of the Department of Humanities of the UFV. Research Focused on: Philosophy (Aesthetics, Anthropology) and Literature.

Dr. Romero Sánchez-Palencia is currently the principal investigator of an international research project on impact on integral training and a member of a research project on literature and hermeneutics. He has won many awards for his teaching work and collaborates with the Université IRCOM in Angers, France. 